\title{
Social Problems Implied in Old Women
}

\author{
Dr. Ashok Dayal \\ Assistant Professor, Department of English, Kaushalya Bharat Singh 'Gandhi' Government Girls Degree College, Dhindhui, Patti, \\ Pratapgarh, (U. P.), India
}

\begin{abstract}
Mahasweta Devi is not only one of the most prolific Bengali authors, but she's also an important activist. In fact, for Devi, the two seem to go together. As you can probably tell from the titles, she writes about women and their place in Indian society. Some of the characters in her stories are old women living in poverty, and some of them are exploited because of their lack of wealth; however, some of them are middle class (one of them is even college-educated). Regardless of their status, though, they all suffer some kind of mistreatment, whether it's physical or mental abuse, but not all of them are willing to accept their fate.
\end{abstract}

Keywords: poverty, subaltern, sociopolitical, resistance

The main concern of the Subaltern writers is to evaluate the position of the marginalized classes in the contemporary social spectrum. Mahasweta Devi's stories articulate subaltern women's insurgency and resistance in the social text of this post-colonial India. Mahasweta Devi is one of the contemporary Bengali writers whose literary expressions gave voice to the silent sufferings of the subalterns in the post-colonial socio-political milieu. She is a socially committed writer who raises her voice against the inhumanistic corrupt socio-political practices in the contemporary Indian scenario. Her stories highlight the failure of Indian nationalism to emancipate lower class subaltern woman. Her stories bring out, "The singularity of each of the disempowered people she engages with tests of the limits of dominant narratives of social change and political representation." (Morton 2007: 47). Indifferences of Government and political parties towards the indiscretionsstock her.

The two stories in the collection Old Women-Statue and The Fairy Tale of Mohanpur, are touching, poignant tales, in both of which the protagonists are old women. Statue (Murti) is a tragic tale of forbidden love, which returns to haunt Dulali, now an old woman pre-occupied only with her day -to -day sustenance. "There are not thirty literate persons in the eight villages" (1). The local power holders never encouraged the boys and girls to study. The children spend their life doing menial works. The primary motto of their life was to pacify the hunger of their bodies and not the needs of their brains.

Hunger is presented as the greatest reality in the life of Dulali. "She has accepted hunger pangs as chronic and inalterable reality." (13) We find her sitting by the hearth even in the months of Boishakh and Joishtho, the hottest months in Bengal. The reason behind was that "with her belly always empty or three-quarters empty, there is nothing left in her body. She likes the fire's warmth and for lack of blood feels chilled all the times." (14). All her thoughts and dreams are belly-centred.

"When she dreams, she dreams crude dreams. In her dreams she wears a whole cloth and eats a full serving of rice in a bell-metal plate. Every day. Only rice. No lentils, no vegetables. Only rice." (16)
Devi portrays the true picture of the superstitious uneducated caste ridden villages of our country. Dulali was married at the age of four and she became a widow at six. Clad in white, her childhood is deprived of the colours of life. In her youth, her beauty attracts the Brahmin Dinu Thakur, which eventually turns out to the downfall of both the families. From that day, she is marked as the misfortune of the Bhunya household. "Rather than kill her physically they kept her in a room raised on the yard's far end." (12).

Dulali has borne injustice all her life. She is kept on ration by her family members, "some rice-salt-oil-lentil at month's end, two saries yearly. "(13) She tries to solve her life's problems in different ways. She collects the pots that are left at Manosha's shrine and sometimes steals lentils from others compound. She wanders in the dense jungle of the Thakur homestead and eats whatever she gets. In this socially secluded state, her mind bubbles with complicated thoughts,

"From earliest consciousness she remembers that she was at once unwanted and indispensable in the household.... Does she belong to this house? If close kin, then why outcast? If not kin, then why is she in the house? If the decision is not to feed her, then why give? If one feels like feeding, why give such a small amount of rice?" (13-14)

Dulali realizes that as time passes, for a woman, the ideology of love remains a memory but she acknowledges defeat in the hands of hunger. It is an exquisite aporia, almost between species-life and species-being. "At seventyeight the body becomes such that today's unappeased hunger appears much more real than the requited love of the past." (27)

On the basis of a researcher's thesis, the subject of the revolutionary martyr DindayalThakur is brought to light. The minister who happens to be from the Chhatim Village decides to build a bronze statue in honour of the great revolutionary. The love story between Dinuda and Dulali is revealed through a letter written by the Thakur before his hanging. It was obvious from the letter that both of them had to face ferocious opposition from the society. "It seems as if unrequited love and participation in revolutionary activities were interdependent. " (18) 
Dinadayal Thakur, the educated revolutionist voiced against the social evils like child marriages and the treatment of widows. Dinu's parents are shocked when he reveals his love for the widowed Dulali and proposes to marry her. He was of the opinion that widow remarriage was possible "both by scriptures and civil law. "In his letter, he questions, "Who says life ends at widowhood? Who says there can be no marriage between a Bhunya and a Thakur?" (18) Thus, the death of Dinu and the social isolation of Dulalimark the failure of political independence to effectively change the class and gender inequalities in Indian society.

Nabin, an educated youth of the village and the compassionate nephew of Dulali, eventually becomes a leader of the deprived classes and start to work for their social upliftment. He dreams of a 'road' that will connect his village with the outer realms of the society. The 'road' is a powerful motif which stands for the deprived past to connect with an equality-oriented future. It also stands for the search for their identity and their purpose in life. In NabinBhunya, is a youth who dreams about the future of his village,

"His enthusiasm is not for the past but for the present...His chief concern is how to make the government spend seventy thousand rupees, lift dead Chhatim village from archaic and twentiethcentury hearsay and half-truths and join modern times by way of road. Health centre, school, road buses, bicycles, and open mini-vans will run. Nabin doesn't care for the past. " (12)

The statue of Dindayal is unveiled at a grand function. But the MLA refuses to agree to their need of a road. The road remains an unfulfilled dream. A disappointed Nabin says,

"They spent 74, 851 rupees for the statue -the dirt road -the function. They could have gold-plated the village with that money Pishi, they would have got road, health centre, school, ev -erything. The living are dead and yet. . ." (72)

The farce of the government is unveiled, for them "the statue of a dead man is much more important than otherliving problems."

In The Fairy Tale of Mohanpur (Mohanpurer Rupakatha), the protagonist Andi loses her eyes through a combination of poverty, societal indifference and governmental apathy. "In that fairy tale there is no starvation, no famine, no despotism from HedoNaskar..." (73) Poverty again plays havoc in the lives of these women, "She picks the bitter thankuni herb, the fruit of the fig, the auspicious durba grass, she scrapes the surface of the muck-choked pond to get land snails to give to Durga..." (74)

The basic necessity of the voting population is neglected by the elected political parties. In both the stories, we find an urging needfor health centre. Andi goes to Irkanpur Health Centre, but the centre is too small to meet the needs of the thousands who pour in with various diseases. There is a scarcity of medicines as well as doctors. Even the Government health plans end to be failures as the illiterate citizens' rush for the books of family planning only to sell the stuff off to the grocer. The condition of the Health Centre hospital is pathetic as it does not even have a trainedadult female nurse. The only doctor of that centre laments on the situation,

"Where will they live here? There's no place to live. They can't come without brick buildings and safe residences. The Health Centre has no surrounding walls and is not secure. Armed robbery and larceny are chronic here. A lot of agitation has not produced a room for the nurse." (79)

Andi suffers from cataract and the doctor sends her back with the hopes. Andi's sons and others work for HedoNaskar, the village land-lord. The Government has ordered for sharecropping, but Naskar has high influence in the leadership of the government. For him it's a 'state-run farce'. He pays his workers according to his convenience. In addition tothis, he owns the fisheries and cold storage. He is also the order supplier for everything at the Health Centre as well as the head of the Panchayat. So the villagers bear all injustice out of fear.

Gobindo, the dedicated hot-tempered communist party social worker toils hard for the betterment of his place. He fights with Naskar to provide little benefits like paraffin, provisions for the health centre. He tries to educate the children of the peasants. He goes to Calcutta and reappears as a trained community health worker. Meanwhile a disappointed Andi approaches a vendor in Jabudpur market. He gives her some medicine which ultimately leads to infection of her eyes turning her blind forever. Gobindo decides to bring the government doctor to operate Andi's eyes. He protests against the system and finally gets her admitted in the hospital. But for Andi, she thinks nothing about her eye-sight. She is contented as "she has been admitted to hospital. She will eat all kinds of things at the hospital, the doctor will come again..." (104)

The blindness of Andi stands as a motif as to how people willfully avoid seeing and confronting the truth. It also stands for people's inability to see what they wish not to see. Many characters like the government doctor, Naskar refuse to acknowledge truths about themselves or their community. Devi's fiction presents the reader with a picture of the subaltern woman's body literally revolting against the post colonial state. At thesame time she presents the extraordinary resourcefulness of this village community of women and the guileless courage and simplicity of Andi.

Mahasweta Devi presents sensitive, delicately-drawn portrait of Dulali and Andi, at the same time delineating the socio-economic oppression within which they are forced to survive. The old women of Mahasweta Devi bring along with them an epoch of their caste and class surroundings, their beliefs, deities and the sweeps of local Communists. The stories highlight the ethical risks that were staked when privileged intellectuals made political claims on behalf of oppressed group. A priori between gendering and the ideology of national liberation are also worth contemplating. Through her stories she brings out the unpleasant truth that national liberation has ended up both as 'tragedy and farce.' 
Delineating through the perspective of Kamala Visweswaran, the character Dulali represents 'woman as subaltern', whereas Andi is an example of 'subaltern women'. Through the portrayal of these two old women, Mahasweta Devi questions the socio-political inequalities related to the neglected sections of society and her struggle is to attain the right of equality in independent India. Her protagonists are often seen struggling against the forces which deliberately resist the process of social regeneration and political rehabilitation. Her presentation of the post independent era of India is very realistic and reveals the pain and pitiable plight of the deprived classes.

\section{References}

[1] Beauvoir, Simone de. The Second Sex. Trans. H. M. Parshley. Great Britain: Vintage, 1997. Print.

[2] Devi, Mahasweta. Old Women. Trans. GayatriChakravortySpivak. Calcutta: Seagull Books, 2002. Print.

[3] Guha, R. Elementary Aspects of Peasant Insurgency in Colonial India. Delhi, Oxford University Press India, 1983. Pp.37-44. Print.

[4] Jung, Carl Gustav. Aspects of the Feminine. Trans. R. F. C. Hull. U. K: Routledge, 2009. Print.

[5] Morton, Stephen. GayatriChakravortySpivak. New York: Routledge, 2007. Print. 